\title{
Odrasli se učimo drugače
}

Ema Perme

\author{
Kadar ob besedi učenje zatrepetamo in zadrgetamo, kadar se naša samozavest spotakne na \\ pragu znanja. Za take trenutke in njihove posledice smo pripravljali program Odrasli se \\ učimo drugače.
}

Program je nastajal z namenom, da bi vsem, ki jim je pretekel daljši čas od kakršnekoli oblike šolanja ali pa jim je to pustilo neprijetno izkušnjo, zmanjšal in zaoblil kamenje, ki bode v podplate zaupanja v lastne sposobnosti in zmožnosti. Nastajal je $\mathrm{z}$ močno željo po tem, da se približamo viziji, da je »učenje lahko prijetno in zabavno«, kot so ob koncu seminarja zapisali tudi nekateri naši udeleženci.

\section{- poimenovanju}

Če se najprej ustavimo pri imenu, naj povemo, da je bil prvi delovni naslov Naučimo odrasle učiti se. Z njim smo želeli kar najbolj natančno poudariti vsebino programa. In sicer, da je namenjen odraslim in da obstajajo novi in drugačni pristopi, ki jih ti odrasli pri svojem šolanju niso spoznali in jim je, tako kot se to dogaja tudi današnjim šolarjem, večkrat ostal grenak spomin na šolsko klop, ki je bolj utesnjevala, kakor osvobajala duha, in spodbujala fantazijsko razmišljanje. To danes še posebej poudarjamo, saj je pogoj za uspešno učenje ter lažje in učinkovitejše pomnenje.

Kljub temu pa je ta prvi naslov nehote vsiljeval in napeljeval na misel, da se odrasli ne znamo učiti, z vsakim zanikanjem in $\mathrm{s}$ prepovedjo pa pristrižemo krila vsem mislim, ki naj bi se same od sebe sprostile in porodile.

Odločili smo se, da naslov seminarja spremenimo v Odrasli se učimo drugače, ki pravzaprav še vedno označuje učni proces $\mathrm{v}$ odrasli dobi, dodaja pa mu tisto pomembno konotacijo, da je zaradi vseh prejšnjih dogodkov in okoliščin ter vlog (otrok, zakonski partner, uslužbenec, starševska vloga ipd.), ki jih še ima, tokrat, kljub vsemu, drugačen.

\section{Učenje: zakøj, kdøj in kje}

Učenje in izobraževanje se v razvoju človeka pojavlja v najmanj dveh izjemnih razsežnostih: kot družbena dejavnost in kot posameznikova aktivnost. Skozi zgodovino pa so učenju in izobraževanju pripisovali različen pomen in vlogo, vsekakor pa verjetno nikoli prej ni bilo toliko tehtnih ugotovitev in potrditev o njegovi pomembnosti za naš skupen razvoj in v domeni zavzemanja za množičnost učenja in izobraževanja kot danes.

Živimo namreč v času, ko je lahko vsaka informacija ki jo dobimo ali pa jo izpustimo, odločilna za naše nadaljnje odločitve. Srečujemo se z različnimi izzivi, tem pa lahko sledimo le z nenehnim učenjem, ki se začne $\mathrm{z}$ rojstvom in konča s smrtjo, med tema dvema dogodkoma pa obstaja neskončno število okoliščin, informacij, vplivov, izkušenj, preprosto rečeno: življenje. Iz tega spoznanja izhaja teorija vseživljenskosti učenja, ki poudarja, da je izobraževanje pogoj zadovoljnega in uspešnega življenja, torej obstaja možnost osebnega razvoja in doseganja višje kvalitete življenja.

\section{Učenje ni samo fehnika, je fudi stvar srca}

Pedagogiko so na kratko opredelili kot umetnost in znanost o vzgoji otrok, to vsekakor je, kadar jo izvajamo v njeni najbolj čisti obliki, saj takrat ustvarja razmere za oblikovanje pozitivne posameznikove naravnanosti na učenje že v zgodnjem obdobju. Vsi vemo, da nas učne navade in tehnike učenja, ki smo jih osvojili v tem obdobju, spremljajo celo življenje. Če nam pri pridobivanju teh pozitivnih izkušenj spodrsne, nosimo vtise in izkušnjo tega spodrsljaja do naslednjega podobnega položaja. Prav zato je vsebinsko polno ter radostno učenje in izobraževanje otrok ter mladine izredno pomembno za uresničevanje strategije koncepta permanentnosti izobraževanja in »vseživljenski proces odkrivanja neznanega«, kot meni znani ameriški andragog M. Knowles.

Pri tem je pomembno, da si posameznik pridobiva znanje, spretnosti in navade na podlagi lastnega prepričanja, želja in interesov, da ima uresničevanje njegovih učnih ciljev zanj poseben pomen, saj si tako $\mathrm{z}$ lastno zavestjo oblikuje take učne navade in pristope, ki so $\mathrm{v}$ skladu $\mathrm{z}$ njegovimi osebnostnimi nagnjenji in mu omogočajo stalno učenje in izobraževanje. Tako postane učenje in izobraževanje sestavni del življenja kot samoumevna, spontana reakcija in delovanje. S takim načinom se namreč ustvarjajo temelji za naslednji poskus »odkrivanja neznanega«.

A. Thomas meni, da je izobraževanje le ena od mnogih tehnologij učenja oziroma »javni odgovor na dejstvo, da se ljudje učijo«. Šolske klopi, kjer organizirano izobraževanje, katerega cilj je poučevanje, pri posamezniku pa naj povzroči učenje, poteka, pogosto vzbujajo občutke manjvrednosti in celo nesposobnosti, saj nam postavljajo mejo med dovoljenim in nedovoljenim, mejo med tistim, ki je nadrejen, in tistim, ki je podrejen. Raziskave procesov pomnjenja in delovanja možganov so pokazale, da je učenje oziroma pomnjenje močno povezano s pozitivnim doživljanjem pri spoznavanju novega, šolska klop v pravkar navedeni »obliki« pa prav gotovo težko oblikuje razmere za pozitivna doživetja. Prav tu se pojavijo neugodna izhodišča za izobraževanje odraslih in motivacijo za vseživljenjsko učenje. Zato je še posebej pomembno oblikovanje trdnih motivacijskih mehanizmov, ki bodo odrasle vodili k nadaljnjemu učenju.

Ravno zato je zelo pomembno, kako organiziramo izobraževanje odraslih in da uporabimo ustrezne pristope pri delu, ki upoštevajo značilnosti odraslega in njegove lastnosti, ki vplivajo na proces učenja.

Način učenja v odrasli dobi je mnogo bolj individualen in raznovrsten. Učenje $\mathrm{v}$ praksi in na podlagi dejanskih razmer ima pri odraslih zelo pomembno vlogo. Odrasli se zato zelo razlikujejo po svojih nagnjenjih, interesih in izkušnjah oziroma po načinu, kako se najbolje učijo. Imajo več izkušenj in znanja, kar določa tudi hitrost sprejemanja novega, saj zmanjšano hitrost reagiranja, ki jo pri odraslih nemalokrat omenjamo, lahko nadomestimo $\mathrm{z}$ večjim predznanjem na določenem področju. Poleg tega razvije- 
jo tudi močnejšo odgovornost za uresničevanje nalog, ki so si jih zadali. Za učenje v odrasli dobi je značilna tudi želja po izmenjavi izkušenj v komunikaciji z drugimi ljudmi, ki omogoča iskanje rešitev med več možnostmi.

\section{Nastajanje programa Odrasli se učimo drugače}

$\mathrm{Z}$ upoštevanjem značilnosti učnega procesa in osebnostnih lastnosti, ki jih razvije odrasli posameznik, ter njegovega doživljanja učenja in izobraževanja je nastajal tudi naš program Odrasli se učimo drugače. Pri načrtovanju smo predvsem želeli oblikovati program, ki bi spodbujal motivacijo, saj je ta še posebej pomembna in pomeni temelj za ohranjanje vedoželjnosti, zato je odločilna pri oblikovanju in ohranjanju vezi med »odraslim učencem« in željo po spoznavanju novih pristopov, metod in tehnik ter načinov učenja, s katerimi lahko dokažemo resnico, da je učenje in izobraževanje del življenja, ki ohranja njegovo kvaliteto.

Izkušnje kažejo, da so odrasli pri vključevanju v daljše izobraževalne programe pogosto neuspešni, predvsem zaradi negativnih izkušenj iz mladosti, nizkega vrednotenja svojih sposobnosti in nepoznavanja novih, drugačnih metod in oblik učenja, ki bi jim lahko bile v veliko pomoč pri osvajanju novega znanja.

V Dobi smo se odločili, da pripravimo učno delavnico, v kateri bomo odrasle seznanili z novimi možnostmi za uspešnejše učenje in tako povečali njihovo zadovoljstvo, motivacijo in prepoznavanje lastnih zmožnosti za učenje.

Ker v programski ponudbi doslej še nismo zasledili takšnega programa, smo poskusili s tem dopolniti sedanjo ponudbo.

Ideja o pripravi takšnega programa je nastala tudi po priročniku nemških avtorjev, ${ }^{1}$ ki smo ga uporabili kot podlago za pripravo posameznih delovnih faz in praktične izvedbo šestnajsturnega programa Odrasli se učimo drugače. Glavni razlog za pripravo pa so bile potrebe v praksi, saj na RZZ OE v Mariboru ugotavljajo zaskrbljiv podatek o osipu udeležencev, vključenih v daljše oblike izobraževanja za pridobitev prvega poklica in programe prekvalifikacij in dokvalifikacij. Poklicni svetovalci so ugotavljali, da se predvsem pri nižje kvalificirani delovni sili, ki se po daljšem času ponovno vključuje v izobraževanje, iz pravkar navedenih razlogov, pojavijo težave pri odločanju za izobraževanje problem motiviranosti. Po sami vključitvi pa se pojavijo težave pri sprejemanju vsebin, zaradi pomanjkanja poznavanja načinov načrtovanja učenja in osnovnih tehnik učenja. Tako smo izvedli sedem eksperimentalnih ponovitev programa, na osnovi dveh pa smo v dogovoru z RZZ Slovenije program tudi analizirali. Rezultati potrjujejo naša pričakovanja.

\section{cililı, vsebina in mefode dela}

\section{Cilii}

Učne delavnice naj bi z aktivnimi delovnimi metodami udeležence spodbudile k samostojnemu razmišljanju in iskanju rešitev ter ugotovitev. Udeleženci programa Odrasli se učimo drugače z aktivnim delom obravnavajo značilnosti učenja pri odraslem, učna nagnjenja, kako oblikovati učne cilje, kako se motivirati in spodbujati $\mathrm{k}$ učenju. Udeleženci programa spoznajo značilnosti in lastnosti posameznih učnih tipov, določajo svoje najugodnejše učno okolje, spoznajo tehnike sproščanja, določijo lastne strate-

\footnotetext{
${ }^{1}$ Beitinger, Mandl, Spodbude za nadaljnje učenje, Doba, Maribor, 1994.
}

gije za načrtovanje učnega projekta, določijo svoj konkretni učni cilj, spoznajo bralne tehnike ter zapisovanje vsebin in informacij $\mathrm{z}$ miselnimi vzorci, ki jih tudi med seminarjem preizkušajo. $\mathrm{Ob}$ koncu seminarja izdelajo svoj osebni učni načrt s povzetkom ugotovitev o učenju in o njihovem osebnem učnem načinu in načrtovanju učenja ter ga zapišejo v obliki miselnega vzorca.

\section{Vsebina:}

\section{- ugotavljanje osebnih učnih nagnjenj}

Določanje učnih tipov (udeleženci izpolnijo test in se prepoznavajo po svojih značilnostih). Določanje najbolj ugodnega okolja za učenje, prostora in socialnega okolja pri vsakem posamezniku. Preizkušanje tehnike sproščanja in analiza občutkov. Spoznavanje glasbe, primerne za sproščanje in koncentracijo.

Vsi v eksperimentalni skupini so se s temi temami srečali prvič, po šestih mesecih, ko smo jih anketirali, pa vsi trdijo, da jim ta spoznanja pri učenju pomagajo.

\section{- načrtovanje učnega projekta}

V tem sklopu spoznajo udeleženci tudi organizirano samostojno učenje, določijo učne cilje in posamezne stopnje pri njihovem uresničevanju, in sicer glede na svoje predznanje, interese, možnosti.

Vsi so določili svoj učni cilj, nekateri tudi dva ali tri, po šestih mesecih je večina trdila, da ga uresničuje po začrtanih stopnjah.

\section{- strategije in tehnike za učenje}

Udeleženci si določijo čas v dnevu, ki ga glede na druge obveznosti lahko namenijo učenju v skladu $\mathrm{z}$ osebnim bioritmom, in določijo osebne motivacijske mehanizme (kdaj načrtovati odmore in kako se razvedriti v krajših ali daljših odmorih). Sem spadajo še: spoznavanje načinov branja, praktični primeri krčenja besedila, luščenje bistva (praktična vaja v parih), spoznavanje zapisovanja z miselnimi vzorci (vaja asociacij), izdelava lastnega miselnega vzorca s temo Povzetek doslej obravnavanih vsebin na seminarju.

\section{- osebni učni načrt}

Na koncu seminarja udeleženci naredijo svoj osebni učni načrt $\mathrm{v}$ obliki miselnega vzorca po stopnjah, ki smo jih opisali, $\mathrm{z}$ upoštevanjem osebnostnih značilnosti, lastnosti in možnosti.

Program spada med krajše oblike usposabljanja. Izhajajoč iz spoznanj pri uvajanju novih oblik dela v izobraževanju odraslih smo načrtovali take oblike dela, ki bi udeležence čimbolj spodbudile $\mathrm{k}$ lastnemu razmišljanju in načrtovanju ter navajanju na lastno aktivnost in odgovornost za doseganje osebnih ciljev.

\section{Metode dela}

Uvodna predavanja, razgovori, animacijske naloge in vaje, samostojno delo, delo v parih, skupinsko/plenumsko delo, različne vaje in naloge za razmišljanje, diskusije za razčlenitev mnenj in stališč so se prepletali med celotnim potekom seminarja, saj na tej podlagi ta nastaja in se oblikuje.

\section{Povzelek ugofovifev $v$ analizi eksperimentalnih izvedb}

$\mathrm{Z}$ analizo eksperimentalnih izvedb smo želeli preveriti primernost in izvedbo programa, ker je bil pripravljen na novo. Da bi ugotovili, katere faze programa je treba dopolniti, kaj je v programu dobro in kakšne učinke na proces učenja ima pri udeležencih, predvsem $\mathrm{z}$ vidika pripravljenosti, volje in motivacije za uče- 
nje, saj je ta pogoj za nadaljnje usmerjanje učenja, smo po pripravljenem inštrumentariju spremljali eksperimentalne izvedbe programa.

\section{Kratek opis vzorca}

Eksperimentalni program Odrasli se učimo drugače smo izvedli v sedmih skupinah, skupaj z RZZ Slovenije je bil oblikovan postopek za analizo izvedbe in učinkovitosti programa $\mathrm{v}$ dveh eksperimentalnih skupinah. Udeleženci eksperimentalnih skupin so bili v program vključeni v septembru in oktobru 1995.

V program so bili vključeni brezposelni, prijavljeni na RZZ OE Maribor, ki jih je vključil v daljše oblike izobraževanja za pridobitev prvega poklica ali prekvalifikacije, smer prodajalec. Ta program jim je predlagal RZZ OE Maribor.

Tri četrtine vključenih je bilo starih med 20 in 25 let, drugi pa so bili stari več kot 25 let. Stopnjo triletne srednje šole je dosegala slaba polovica udeležencev, 20 odstotkov je bilo takih, ki so končali program enoletnega usposabljanja po osnovni šoli, tretjina, vključenih v naš program, pa je končala osnovno šolo.

Čas, ki je pretekel od takrat, ko so udeleženci našega programa končali redno šolanje, je bil tako v povprečju daljši od pet let.

Tudi podatek o tem, kako dolgo so brezposelni, je za pričakovanje visoke stopnje motiviranosti dokaj neugoden, saj je bila več kot polovica udeležencev našega programa več kot dve leti brezposelna.

\section{Ob koncu seminarja}

$\mathrm{Z}$ anonimno anketo udeležencev smo takoj po končanem seminarju želeli ugotoviti učinke seminarja. Uporabili smo dva inštrumentarija, z njima pa smo zajeli stališča, mnenja, predloge, ocene udeležencev o izvedbi, organizaciji, vsebini, zadovoljstvu, izpolnitvi pričakovanj in podobno. Želeli smo torej dobiti čim več povratnih informacij o programu in izvedbi.

Iz njihovih ocen, mnenj in stališč lahko na splošno povzamemo, da jim je bil program dobro predstavljen, prav tako cilji, vsebino seminarja so označili kot zelo koristno in zanimivo, predavatelja pa so ocenili kot zelo dinamičnega, razumljivega, duhovitega in vsekakor spodbudnega. Zadovoljni pa so bili tudi z organizacijo.

Četrtina udeležencev je menila, da je bil program prekratek, dodali pa so še, da bi pri posameznem tematskem sklopu potrebovali poglobitev znanja.

Štiri petine udeležencev je odgovorilo, da bi program priporočili tudi svojim znancem.

\section{Šesł mesecev po končanem seminariju}

Po šestih mesecih smo vključene v eksperimentalno izvedbo, skupaj z RZZ, povabili na razgovor in jih tudi anonimno anketirali. Želeli smo zvedeti, koliko pri svojem učenju uporabljajo vsebine, ki so jih obravnavali, spoznali in utrdili na seminarju.

Ker program spada med krajše oblike usposabljanja in obravnava vsebine in pristop, s katerimi naj bi nadomestili sedanji vzorec, ki ga po navadi uporabljamo več let, smo bili z odgovori zelo zadovoljni.

Odgovori kažejo, da za dve tretjini udeležencev lahko trdimo, da bosta pri nadaljnjem učenju še uporabljali miselne vzorce, dve tretjini udeležencev uporabljata tehnike sproščanja, prav tako pa dve tretjini pri učenju redno uporabljata ustrezno glasbo za koncentracijo in sproščanje. Poudarili pa so, da jim zelo pomaga časovno načrtovanje in razporejanje časa za učenje, saj so vsi odgovorili, da obravnavana načela in ugotovitve na seminarju upoštevajo. Prav tako so potrdili, da jim pri učenju pomaga ugotovitev o njihovem prevladujočem učnem tipu, o njegovih značilnostih, zato so pri učenju bolj učinkoviti. Učni cilj, ki so si ga udeleženci zadali, večina v celoti izpolnjuje po začrtanih stopnjah. Vsi se strinjajo s trditvijo, da je učenje lažje, ker so obiskovali ta seminar.

Na vprašanje, kaj so si na seminarju najbolj zapomnili, smo po šestih mesecih dobili naslednje odgovore: miselne vzorce, tehniko sproščanja, učni tip, razporejanje časa za učenje, kako se spodbujati k učenju, uresničevanje učnega cilja po stopnjah, kako si ustvariti učenje bolj prijetno, dobra družba, sproščeno in prijetno ozračje.

Dodali pa so še, da je bil seminar prekratek in da bi bilo treba pri vsaki temi seminar še poglobiti. Dobili smo še odgovore kot: seminar je bil popoln, ne bi spreminjala seminarja, večkrat bi se morali srečati, seminar bi svetovala svojim prijateljem in znancem, ker pomaga pri načrtovanju učenja.

\section{Namesto sklepa}

$\mathrm{Z}$ neizmernim veseljem pravzaprav zapišem, da se še vedno oglašajo tisti, ki so bili na seminarju pred dobrega pol leta in več, da radi povedo, kako je »bilo dobro« in »da bi se morali dobiti še kdaj« ter da se »sedaj lažje lotimo učenja«.

Tri, včasih dva, dni vtisov, informacij, doživetij, ki so ostali v spominu, kar odsevajo v sijočih očeh gospe, mladenke, mladeniča, ki so bili na seminarju.

Tako prijetno je za nasvidenje slišati preprosto besedo hvala, saj je bila vedno izrečena $\mathrm{Z}$ veliko hvaležnostjo.

Učenje je, tako kot vse, kar počnemo, tudi stvar srca. In če smo v šestnajstih urah skupnega pretresanja misli, izkušenj, načrtov, ciljev in drugih informacij ustvarili tako močan vtis, da so na našem srečanju po šestih mesecih udeleženci eksperimentalnih skupin odgovorili: zdaj si pa res znam izpisovati iz knjig, moj čas je bolje organiziran, ja, tista tehnika sproščanja mi pa res pomaga, moja koncentracija je popolnoma drugačna, hrup me sploh več ne moti, bolje načrtujem in razporejam čas za učenje, od takrat naprej uporabljam miselne vzorce in podobno, potem smo s seminarjem dosegli cilj, ki smo ga želeli doseči.

Ema Perme

Doba, Zavod za izobraževanje 